\title{
A Comparative Analysis of Different Species of Fungi Associated with Oil and Non-Oil Garri (Cassava Flour) Sold in Mudalawan Market, Bauchi State, Nigeria
}

\section{Rabiu Ibrahim ${ }^{1}$, Iornenge Aondoaseer ${ }^{1}$, Bashir Ismail Olawale ${ }^{2}$, Hauwa Tahir ${ }^{1}$, Bishir Musa ${ }^{3,4}$, Umaru Ayuba Alfa ${ }^{5}$}

${ }^{1}$ Abubakar Tatari Ali Polytechnic

P. M. B. 0094, Bauchi, 740272, Nigeria

${ }^{2}$ Abubakar Tafawa Balewa University

Dass road, P. M. B. 0248, Bauchi, 740272, Nigeria

${ }^{3}$ Ahmadu Bello University

Zaria, 810211, Nigeria

4 University of Hohenheim

1 Schloss Hohenheim, 70599, Stuttgart, Germany

${ }^{5}$ College of Education Gindiri

Mangu, Plateau State, Nigeria

DOI: $10.22178 /$ pos.77-10

LCC Subject Category:

QH1-278.5

Received 21.11.2021

Accepted 25.12.2021

Published online 31.12.2021

Corresponding Author:

rabs007@yahoo.com

(c) 2021 The Authors. This

article is licensed under a

Creative Commons Attribution

4.0 License @ (1)

\begin{abstract}
In this study, different species of fungi associated with oil and non-oil Garri were isolated at Mudalawal market, Bauchi State, Nigeria. A total of eight different samples were obtained inside a sterile container and transported to the microbiology laboratory at Abubakar Tatari Ali Polytechnic Bauchi state for analysis. Malt Extract Agar was used for the isolation and identification; about five fungal species were isolated and identified using the standard method of Microbiological techniques. Penicillium spp. (26.9\%) had the highest occurrence in oil and non-oil Garri, followed by Aspergillus spp. (23.1\%), and Rhizopus spp. (19.2 \%) with Fusarium spp. and Mucor spp. having the minor frequency of $15.4 \%$. Higher fungal species were isolated from non-oil Garri compared to oil Garri samples. Moisture content recorded showed higher Oil Garri than in the Non-oil Garri. The fungi isolated were characterized and identified based on their morphological and colonial appearance. The results show that consumers are exposed to the risk of aflatoxin poisoning. Efforts should therefore be made to improve the quality of Cassava by addressing its handling and processing practices.
\end{abstract}

Keywords: . Garri; Fungi; Identification; Morphology; Aflatoxin.

\section{INTRODUCTION}

It's conceivable that "Garri" is a word coined from Hausa origin, a language widely spoken in West Africa that means "powdery or ground substance". For example, Garrin Kwaki-powdery substance made from Cassava, Garrin Masarapowdery substance made from Maize, Garrin Dawa-powdery substance made from Guinea corn, Garrin Magani-powdery or grounded medicine and the list could still go on [11].

But our focus is on "Garrin Kwaki", a product of the Cassava plant also popularly found in Africa [19]. Grounded food was a great idea centuries ago because more modern and improved means of travelling and food preparation available nowadays wasn't the case. So travellers had to spend long days on the road moving from one place to another, and having to cook food during their transit wasn't a luxury $[8,21]$. Hence, the importance of grinding and processing foods that can be eaten as cereals or in their dry powdery form [13].

Garri is food in the Carbohydrates family that can be made from Cassava by peeling the roots, washing it clean, grating it into Mash to remove some cyanide from it in the process, soaking in 
water to ferment the Mash, draining the Garri mash, sieve into grits, frying the spirits to form the Garri, spreading the Garri for it to cool and sieve it to remove the bigger particles. Now the Garri is made and ready to be stored for consumption. Optionally palm oil can be added during the frying process to change the colour to a bright yellow colour as well as incorporate the health benefits of the palm oil into the Garri [20, 5].

This rich and healthy carbohydrate food can be stored in airtight bags or containers, not affected by wind [8]. It can be made to eat by pouring it into hot boiling water and adequately mixed into a thick pulp (popularly known as "Eba") and eaten with soups or stew (and this combo locally referred to as "swallow"). It can also be garnished with milk, sugar, groundnut etc. and eaten dried as a snack or soaked in cold water and eaten. It can also be consumed directly in its dried form without garnishing coconut, smoked fish, or bean cake (moi-moi) [17, 18].

Well, as nutritious and convenient as Garri can be, it is observed that there exist unhygienic methods encountered during the processing of the cassava roots into Garri and post-processing handling procedures like spreading the grits on the floor after frying to dry or by showcasing it in open bowls or buckets in the markets to sell; and sometimes the roots are not adequately washed before grating it into Mash which may be due to lack of clean water supply and thus can transfer germs and harmful microorganisms from the plant on to the finished product $[7,6]$.

Also, packaging materials used to transport and store Garri, especially when moving them from villages where they were produced to the cities or from farms to where they can be sold, are very important to take note of as some may be dirty before use and may have harmful deposits of rodents and insects. Hence, every item and person involved in Garri production from the harvesting stage of the cassava plant until the sale of the Garri must follow proper healthy practices [9, 22].

\section{METHODS}

Some samples of Garri were aseptically collected using sterile gloves from sellers at Mudalawan Market, Bauchi, Bauchi State, Nigeria. The pieces were then put in clean polythene leather bags and transported to Abubakar Tatari Ali Polytechnic Bauchi for immediate analysis.
The spread plating method was adopted as described by [15]. Two $g$ of the sample weighed was put into a test tube containing $10 \mathrm{~mL}$ sterile distilled water aseptically and was allowed to mix for 3 minutes. Serial dilution was further carried out to obtain a dilution of $10^{-4}$ as described by [12].

An aliquot of $0.1 \mathrm{ml}$ of $10^{-4}$ serial dilution of the sample was spread on Malt Extract Agar and was incubated at $25{ }^{\circ} \mathrm{C}$ for $78 \mathrm{hrs}$. After incubation, total viable fungal counts were carried out and expressed as propagules per gram (propagules/ grams) of the sample. The fungal isolated were isolated and identified based on their morphological characteristics and microscopic view as described by [3]. The fungal isolates pure colony was then obtained after subculturing.

$10 \mathrm{~g}$ of the sample was mixed in $10 \mathrm{~mL}$ distilled water, and the $\mathrm{pH}$ of the suspension was determined using a reference glass electrode $\mathrm{pH}$ meter as described by [15].

The moisture content was determined according to the standard of [4]. The crucibles were washed and dried in an oven at $100{ }^{\circ} \mathrm{C}$ for one hour, and the weight was noted as $W_{1}$. Two grams of each of the samples was separately weighed into crucibles, and their consequences were taken and noted down as $\left(\mathrm{W}_{2}\right)$ before and after drying at $100{ }^{\circ} \mathrm{C}$ to a constant weight $\left(\mathrm{W}_{3}\right)$

Moisture content $=W_{2}-W_{3} \times 100=$
$=$ weight of moisture $\times 100$

where $\mathrm{W}_{1}$ - the weight of the empty crucible; $\mathrm{W}_{2}$ - the weight of crucible and sample before drying; $\mathrm{W}_{3}$ - the weight of the piece after drying to a constant weight [4].

\section{RESULTS AND DISCUSSION}

Eight of (both oil and non) Garri were analyzed, out of which Penicillium spp. had the higher recurrence of $26.9 \%$ while Fusarium spp. furthermore, Mucor spp. had minimal occurrence, with both having $15.4 \%$, as displayed in (Table 1 ).

The moulds separated had diverse morphological forms on samples investigated with Aspergillus spp., Fusarium spp., Penicillium spp., Mucor spp. and Rhizopus spp. that is significantly at $(\mathrm{P} \geq 0.05)$ both on yellow and white correspondingly. The presence of the pathogens might be due to the technique for handling, openness to bio-vapour sprayers during deal on the lookout and post handling treatment of such item. 
Table 1 - Frequency of Occurrence of Fungal Isolates

\begin{tabular}{|l|l|l|l|l|l|l|l|l|l|c|c|}
\hline \multirow{2}{*}{ Fungal Isolate } & \multicolumn{7}{|c|}{ Sample Code } & \multicolumn{2}{c|}{$\begin{array}{c}\text { Number } \\
\text { of Occurrences (n=26) }\end{array}$} & Percentage (\%) \\
\cline { 2 - 9 } & $\mathrm{A}^{-}$ & $\mathrm{A}^{+}$ & $\mathrm{B}^{-}$ & $\mathrm{B}^{+}$ & $\mathrm{C}^{-}$ & $\mathrm{C}^{+}$ & $\mathrm{D}^{-}$ & $\mathrm{D}^{+}$ & 23.1 \\
\hline Aspergillus spp. & + & - & + & + & + & + & + & - & 6 & 15.4 \\
\hline Fusarium spp. & + & + & - & + & - & - & + & - & 5 & 19.2 \\
\hline Rhizopus spp. & - & - & + & + & - & + & + & + & 7 & 26.9 \\
\hline Penicillium spp. & + & + & + & + & + & + & + & - & 4 & 15.4 \\
\hline Mucor spp. & + & - & - & - & + & + & + & + & & 100 \\
\hline \multicolumn{1}{|c|}{ Total } & 4 & 2 & 3 & 4 & 3 & 4 & 5 & 1 & & 7 \\
\hline
\end{tabular}

Notes: A - Retailer A; B - Retailer B; C - Retailer C; D - Retailer D; $n=26$; - negative; + = positive.

The most significant number of Penicillium spp. recorded concurs with that reported by [2] that found great pervasiveness in Ghana. The outcome also agrees with the work is seen by [15], who separated comparative organisms from matured Cassava not taken care of efficiently [14] likewise revealed the separation of comparative moulds out of Garri concentrate during the evaluation of some aged Cassava items.

The outcomes indicated that white and yellow Garri accommodate several parasitic contaminations as revealed in different examinations. Penicillium spp. and Aspergillus spp. were the most dominating mould found individually in yellow and white Garri assessments. On the contrary, the work of [1] revealed Aspergillus spp., and Penicillium spp., with most higher activities separately.

Moulds have been found to have harmful effects on the body of humans, and their presence in food could put purchasers in danger. For example, Aspergillus spp. was the causative agent of dark shape illness in organic products, ear diseases in humans, and food adulteration. Penicillium spp. contains chemical substances that had been found to have hepatotoxic and cytotoxic impacts. The present research also found out that white Garri had higher humidity content than yellow Garri, and this could be attributed to the fact that yellow Garri typically blended with palm oil during handling and as such debilitating development of the moulds [10] revealed that the significant variable that could energize form pollution and expansion of Garri is the high introductory dampness or growth in dampness content during stockpiling.
Table 2 - Moisture Content and pH Parameters of the Garri Samples

\begin{tabular}{|l|c|c|}
\hline Sample Code & $\begin{array}{c}\text { Moisture } \\
\text { Content }\end{array}$ & pH Content \\
\hline A- & 8.4 & 4.81 \\
\hline A+ & 11.2 & 4.90 \\
\hline B- & 9.0 & 4.90 \\
\hline B+ & 11.4 & 4.86 \\
\hline C- & 9.6 & 4.80 \\
\hline C+ & 7.2 & 4.81 \\
\hline D- & 8.4 & 4.82 \\
\hline D+ & 10.6 & 4.78 \\
\hline
\end{tabular}

Notes: A - Retailer A; B - Retailer B; C - Retailer C; D - Retailer D; - = non-oil Garri; + = oil Garri.

Table 3 - Shows the Colonial and Morphological Appearance of Fungal Isolates

\begin{tabular}{|l|l|l|}
\hline Fungal Isolate & $\begin{array}{l}\text { Colonial } \\
\text { Characteristics }\end{array}$ & $\begin{array}{l}\text { Morphological } \\
\text { Appearance }\end{array}$ \\
\hline Fusarium spp. & $\begin{array}{l}\text { Moderately } \\
\text { growth that } \\
\text { appears white }\end{array}$ & $\begin{array}{l}\text { Sporangiophores } \\
\text { are erect and } \\
\text { mostly } \\
\text { unbranched }\end{array}$ \\
\hline Mucor spp. & $\begin{array}{l}\text { Fast growth } \\
\text { colony, with } \\
\text { abundant woody } \\
\text { aerial mycelium }\end{array}$ & $\begin{array}{l}\text { Sporangiophores } \\
\text { are erect and } \\
\text { mostly } \\
\text { unbranched }\end{array}$ \\
\hline Rhizopus spp. & $\begin{array}{l}\text { Fast growth } \\
\text { colony }\end{array}$ & $\begin{array}{l}\text { Presence of stolen } \\
\text { and pigmented } \\
\text { rhizoids }\end{array}$ \\
\hline Penicillium spp. & $\begin{array}{l}\text { Moderate } \\
\text { growth colonies } \\
\text { that appear } \\
\text { white }\end{array}$ & $\begin{array}{l}\text { Phialides may } \\
\text { produce singly or } \\
\text { in group }\end{array}$ \\
\hline Aspergillus spp. & $\begin{array}{l}\text { Colonies appear } \\
\text { light to green } \\
\text { with the } \\
\text { moderate } \\
\text { growth rate }\end{array}$ & $\begin{array}{l}\text { Typically blue- } \\
\text { green with a } \\
\text { suede-like } \\
\text { structure }\end{array}$ \\
\hline
\end{tabular}


Table 4 - Propagules/g of the Garri Samples Collected

\begin{tabular}{|l|l|}
\hline \multicolumn{1}{|c|}{ Sample Dilution } & \multicolumn{1}{c|}{ Ranges of Propagules/g } \\
\hline Sample A+ & $2.8 \times 10^{1}-2.4 \times 10^{4}$ \\
\hline Sample A- & $2.7 \times 10^{1}-2.0 \times 10^{4}$ \\
\hline Sample B+ & $2.9 \times 10^{1}-2.3 \times 10^{4}$ \\
\hline Sample B- & $2.7 \times 10^{1}-2.1 \times 10^{4}$ \\
\hline Sample C+ & $3.4 \times 10^{1}-2.2 \times 10^{4}$ \\
\hline Sample C- & $2.5 \times 10^{1}-1.0 \times 10^{4}$ \\
\hline Sample D+ & $2.6 \times 10^{1}-1.1 \times 10^{4}$ \\
\hline Sample D- & $2.4 \times 10^{1}-1.0 \times 10^{4}$ \\
\hline
\end{tabular}

\section{CONCLUSIONS}

The presence of fungi associated with Garri could be attributed to the production processes of the products. The contamination could be introduced by spreading the grounded cassava flour on a mat during processing and packaging. The methods generally adopted by the retailers in the cause of selling this product could also attract many pathogens into the food since these products usually are displaced in an open bowl within the market vicinity. The majority of the fungi isolated in this research are agents of diseases. Their ability to produce mycotoxins can have a profound health effect on man.

The non-oil (white) Garri had more fungal species isolates than oil (yellow) Garri. The fungi were isolated and characterized based on their morphological and colonial characteristics. The higher number of fungi isolates recorded in this research indicates the risk of food poisoning imposed on consumers when they are exposed to this cassava product.

\section{Acknowledgements}

Special gratitude to the co-authors and supervisors for their time dedicated to this study. Also, to learned colleagues that contributed to the success of this work.

\section{Conflict of interests}

The authors declare no conflicting interests.

\section{REFERENCES}

1. Agu, G., \& Olufunmilayo, O. (2016). Sodium dodecyl sulphate polyacrylamide gel electrophoresis (SDS-PAGE) of fungal contaminant of garri. Microbiological Research International, 4(2), 11-16.

2. Aguoru, Onda, Omoni, V. T., \& Ogbonna, I. O. (2014). Characterization of moulds associated with processed garri stored for 40 days at ambient temperature in Makurdi, Nigeria. African Journal of Biotechnology, 13(5), 673-677. doi: 10.5897/ajb2013.12187

3. Alexopoulus, C., Mims, C., \& Blackwell, M. (1996). Introductory Mycology (4th ed.). New Delhi: Wiley India Pvt.

4. AOAC. (2019). Official Methods of Analysis (21st ed.). Retrieved from https://bit.ly/3f7Vrk8

5. Asegbeloyin, J. N., \& Onyimonyi, A. E. (2007). The Effect of Different Processing Methods on the Residual Cyanide of 'Gari'. Pakistan Journal of Nutrition, 6(2), 163-166. doi: 10.3923/pjn.2007.163.166

6. Chikezie, P., \& Ojiako, O. (2013). Cyanide and aflatoxin loads of processed cassava (Manihot esculenta) tubers (Garri) in Njaba, Imo state, Nigeria. Toxicology International, 20(3), 261. doi: 10.4103/0971-6580.121679

7. Ekundayo, C. A. (1984) Microbial Spoilage of Packaged Garri in Storage. Microbiology Letters , 23, 271-278.

8. Ernesto, M., Cardoso, A. P., Cliff, J., \& Bradbury, J. H. (2000). Cyanogens in Cassava Flour and Roots and Urinary Thiocyanate Concentration in Mozambique. Journal of Food Composition and Analysis, 13(1), 1-12. doi: 10.1006/jfca.1999.0847

9. Gautier, M., Normand, A.-C., \& Ranque, S. (2016). Previously unknown species of Aspergillus. Clinical Microbiology and Infection, 22(8), 662-669. doi: 10.1016/j.cmi.2016.05.013

10. Halliday, D., Quareshi, A., \& Broadbent, J. (1967). Investigations on the storage of garri. Research Institute and Technical Report, 16, 131-141. 
11. Jekayinfa, S. O., \& Olajide, J. O. (2007). Analysis of energy usage in the production of three selected cassava-based foods in Nigeria. Journal of Food Engineering, 82(2), 217-226. doi: 10.1016/j.jfoodeng.2007.02.003

12. Jonathan, G., Ajayi, I., \& Omitade, Y. (2011). Nutritional compositions, fungi and aflatoxins detection in stored 'gbodo' (fermented Dioscorea rotundata) and 'elubo ogede' (fermented Musa parasidiaca) from South western Nigeria. African Journal of Food Science, 5(2), 105-110.

13. Nweke, I. (1988). Effect of cassava processing and cassava utilization. International Institute of Tropical Agriculture, 1, 5-8.

14. Obadina, A. O., Oyewole, O. B., \& Odusami, A. O. (2009). Microbiological safety and quality assessment of some fermented cassava products (lafun, fufu, gari). Scientific Research and Essay, 4(5), 432-435.

15. Ogiehor, I. S., \& Ikenebomeh, M. J. (2005). Extension of shelf life of garri by hygienic handling and sodium benzoate treatment. African Journal of Biotechnology, 4(7), 744-748.

16. Ogiehor, I. S., Ikenebomeh, M. J., \& Ekundayo, A. O. (2007). The bioload and aflatoxin content of market garri from some selected states in southern Nigeria: public health significance. African Health Sciences, 7, 223-227.

17. Ogugbue, C. J., \& Obi, G. (2011). Bioburden of Garri Stored in Different Packaging Material under Tropical Market Conditions. Middle-East Journal of Scientific Research , 7, 741-745.

18. Ogugbue, C. J., Mbakwem-Aniebo, C., \& Akubuenyi, F. (2011). Assessment of microbial air contamination of post processed garri on sale in markets. African Journal of Food Science , 5, 503512.

19. Oluwole, O., Olatunji, O., \& Odunfa, S. (2005). A Process Technology For Conversion Of Dried Cassava Chips Into “Gari.” Nigerian Food Journal, 22(1). doi: 10.4314/nifoj.v22i1.33570

20. Orakpo, E. (2013, May 9). IITA to eliminate vitamin A-induced malnutrition with fortified cassava. Retrieved from https://bit.ly/3Fe8Xxc

21. Scott, J. (Ed.). (1992). Products development for roots and tuber crops (Vol. 3). Lima: International Potato Center.

22. Steinkraus, K. H. (1997). Classification of fermented foods: worldwide review of household fermentation techniques. Food Control, 8(5-6), 311-317. doi: 10.1016/s0956-7135(97)00050-9 